ANTAL Tamás

DOI: 10.15170/DIKE.2019.03.02.03

Accociate professor, Dr. habil.

University of Szeged

\title{
Chapters from the History of the Hungarian Ministry of Justice in World War II ${ }^{1}$
}

The author deals with four special issues from the history of the Ministry of Justice during the period mentioned in the title: the jurisdictional challenges in connection with the re-occupation of the so-called Southern Territories which were lost by the Treaty of Trianon; the scope of authority and the duties of the Service for National Policy organized in 1940; the new task of the Supervising Authority of Public Interests coming from the implementation of the Jewish laws; finally the mission of Minister Gábor Vladár at the end of the Hortby era.

Keywords: Ministry of Justice, World War II, Southern Territories, Jewish laws, judicature

The elaboration of the history of the Hungarian Royal Ministry of Justice poses a major challenge due to the destruction of the files in the Hungarian National Archives in 1956. In my present paper, I would like to highlight brief chapters that can be considered important from among the remaining fragmentary material.

\section{Jurisdictional challenges after re-occupation of the Southern Territories}

As a result of the Vienna Awards $(1938,1940)$, on the one hand, the administration of justice had to be maintained, and on the other hand, the Hungarian state legislation had to be organized again in, as called officially, the territories returned to the Holy Crown of Hungary, which was the responsibility of the Ministry of Justice and the Government. The first relevant decree entered into force on 28 October, $1938 .^{2}$ In the territories of Felvidék (Upper Hungary), Transcarpathia and Transylvania concerned, the procedural rules of private law, civil and non-litigious proceedings in force there at the time of their re-annexation - namely on 1 January, 27 June, 1939, and 26 November, 1940, respectively - were generally maintained, while in criminal justice the Hungarian law had to be applied. The commencement of the operation of the Hungarian courts entailed that the ongoing deadlines were interrupted and restarted, and the time interval between the dissolution of the Czechoslovakian and Romanian courts and the beginning of the operation of the Hungarian forums was not included in the limitation period. The appeal court in Kassa (Košice) was reestablished in 1938, while the ones in Kolozsvár (Cluj, Klausenburg), Nagyvárad (Oradea) and

\footnotetext{
${ }^{1}$ This paper is the edited version of the author's presentation on the workshop „Theorie und Praxis der Entrechtung in der zweiten Hälfte der Horthy-Ära im Vergleich mit dem NS-Regime” (Pécs, 2-6 September 2019).

${ }^{2}$ Decrees of the Hung. Royal Government No. 7.780/1938; No. 9.600/1938; No. 5.800/1939; No. 7.810/1940.
} 
Marosvásárhely (Târgu Mures) in 1940. The organization was mostly carried out on decree level in view of swiftness and Hungarian traditions ${ }^{3}$ as well as the war-time public law conditions as of September 1939, but these rules of law are so numerous that only their listing would be beyond the scope of the present study.

The judicial integration of Délvidék (Southern Territories) occupied in the spring of 1941 also took place by this analogy. ${ }^{4}$ As these are geographically closer to Pécs, I will now briefly elaborate on them. Entering World War II in April 1941 resulted in the occupation of the so-called Southern Territories, which then belonged to Yugoslavia according to the Peace Treaty of Trianon (Act XXXIII of 1921), and in its de facto re-annexation to the motherland within a few weeks. However, the public law aspect of all this required much longer time: it was only at the very end of the year that the Governor, Miklós Horthy promulgated Act XX of 1941, which - by analogy with earlier similar laws ${ }^{5}$ - was necessary for the unification of the country in the public law sense. As regards the restoration of Hungarian jurisdiction and citizenship, the theoretical date of 11 April, 1941 was set by Parliament, while leaving the elaboration of all the details of the act in question to regulatory provisions by the Government and the Ministers - including the operation of the judicial organs and the aspects of the concrete laws to be applied. Thus, partly the reinstatement of the force of the former Hungarian rules of law, which did not require new legislative acts, and partly the extension of the territorial scope of the newly-created Hungarian legal norms as well as the implementation of several provisional rules of law were realized during 1941 and 1942. ${ }^{6}$

As of 16 August, 1941, the provisional organizational norms re-established the royal tribunals and public prosecutor's offices in Szabadka (Subotica), Zombor (Sombor) and Újvidék (Novi Sad), as well as several district courts in these areas, most of which were assigned to the district of the Appeal Court of Szeged. The district courts of Dárda (Darda), Muraszombat (Murska Sobota), Alsólendva (Donja Lendava), Csáktornya (Čakovec) and Perlak (Prelog) were added to the areas of the tribunals of Pécs, Szombathely, Zalaegerszeg and Nagykanizsa. In Újvidék, an independent bar association was also set up. ${ }^{7}$ In private law disputes, regulated by the Code of Civil Procedure of 1911 and the act on its entry into force, generally the Hungarian law came into force - at the same time as the Hungarian courts became operational.

Until the end of 1943, appointments for the posts of judge or royal prosecutor in the courts and public prosecutor's offices working in the re-annexed territories could be given to those who had the qualifications for the post of judge or prosecutor required by law applicable in that part of Yugoslavia on 11 April, 1941, provided that they also satisfied the Hungarian requirements necessary for the appointment. In lack of a sufficient number of judges and prosecutors to be appointed or relocated, until the end of 1941 the minister of justice could give temporary commission to judicial or prosecutorial service there for up to six months. ${ }^{8}$

\footnotetext{
${ }^{3}$ RADY, Nonnisi in sensu legum? 15-17.

${ }^{4}$ Decree of the Hung. Royal Government No. 5.470/1941.

5 Acts XXXIV of 1938, VI of 1939, XXVI of 1940.

${ }^{6}$ Especially: Decrees of the Hung. Royal Government No. 6.100/1941 and No. 7.600/1941 on the amendment of the pervious one; No. 6.140/1941; No. 7.550/1941; No. 1.930/1942; No. 2.810/1942.

7 Decree of the Hung. Royal Government No. 5.470/1941 (1-5. Jg); No. 5.620/1941; No. 6.150/1941; No. 8.000/1941; No. 610/1942.

${ }^{8}$ See above Decree No. 5.470/1941, 6-7., 23-24. \$S.
} 
As a rule, in the re-annexed territories the newly-created or already existing Hungarian courts took over the cases which were still pending before a Yugoslav court at the time of its dissolution, or which were in progress before a judge appointed by the Hungarian military authority. Exceptions were the cases which belonged to administrative authorities under Hungarian law, those which did not fall within the scope of jurisdiction of the Hungarian state organs under private international law, proceedings taken by or against the Yugoslav State, and finally, proceedings taken by or against other public bodies or public institutions which could be replaced by another person/organ as a result of the change in state authority. Cases in which new proceedings could be initiated were settled by the Hungarian court replacing the competent Yugoslav court even if otherwise it did not fall within the scope of its jurisdiction or competence under the Hungarian procedural law. ${ }^{9}$

Military criminal justice exercised temporarily over civilians in the re-annexed Southern Territories ceased on 3 August, 1941. As from the following day, criminal cases against civilians were heard by ordinary criminal courts unless the proceedings - pursuant to special law - belonged to the competence of the military criminal court in other parts of the country as well. In cases where the Yugoslav courts had already made a final judgment before 11 April, 1941 and no new criminal proceedings could be initiated, or such proceedings had not yet been initiated before the Hungarian judicial authorities, the person who had been convicted by the Yugoslav court could request the competent Hungarian tribunal (district court) to declare that he/she had not committed the offense that he/she was accused of, or that his/her conviction had not been in accordance with the legal conception of Hungarian law. If the Hungarian court subsequently found that the applicant had not committed the criminal offense that he/she was accused of in the judgment, or that his/her conviction had not been in accordance with the legal conception of Hungarian criminal law, the convict would not suffer any further prejudice on account of the decision of the former Yugoslav court. The Hungarian court could also declare that the judgment of the Yugoslav court was legally invalid in Hungary and it made a new decision instead. If there was any doubt as to the nature of the Southern Territories during the application of the temporary rules, the court or the public prosecutor's office was obliged to turn to the Minister of Justice, whose statement concerning the case was binding on the courts, too. ${ }^{10}$

The Hungarian rules of law of 1914 regarding the administration of courts and royal prosecutor's offices ${ }^{11}$ also entered into force in the Southern Territories on 1 January, 1942, with minor temporary amendments.

Many requested to be relocated to the regions temporarily re-annexed to the country. For example, we know that in 1941 Ferenc Orosæi, an appeal court judge in Kassa, requested the Minister of Justice to be commissioned to re-organize the tribunal in Szabadka, Újvidék or Zombor since he had come from the Southern Territories, and a senior clerk in the tribunal in Nagykanizsa, along with others, urged to be relocated to Transylvania in the previous year. ${ }^{12}$

\footnotetext{
${ }_{9}^{9}$ Decrees of the Hung. Royal Government No. 5.480/1941 (1-6. \$S); No. 730/1942. See further more No. 1.990/1942.

${ }^{10}$ Decree of the Hung. Royal Government No. 5.490/1941 (1-15. \$S).

11 ANTAL, A Szegedi Királyi Ítélőtábla története 1914 és 1921 között 79-91.

${ }^{12}$ MNL OL K577, B.5. 1941. 1-5. f.; B.7. 1941. 1-14. f.; B.8. 1941-1944. 1-66. f.
} 


\section{Authority and duties of the Service for National Policy organized}

At the end of the year, the Service for National Policy (Nemzetpolitikai Szolgálat), which was organized at the Prime Minister's Office in 1940, strongly asked the ministries that, within their competence, their leaders should send information twice a month on "any measure which, directly or indirectly, promotes the material or moral benefit of any social stratum of the nation". The Service for National Policy intended to publish the received material in a bimonthly publication on the operation of the state and municipalities as well as the agencies and institutions under their supervision. The publication "aims to tell and inform the broad spectrum of the Hungarian society about the operation of the Government, thus promoting the development of a correct public perception” - as stated by László Radocsay, Minister of Justice about the aim to be achieved, therefore in December 1940 he ordered that the head of each department should communicate the information in writing to the presidential department of the Ministry until the 1st and 16th day of the month, which was then forwarded to the Service for National Policy. ${ }^{13}$ The propaganda publication was published from January 1941 under the title Országépítés (Landbuilding). ${ }^{14}$

It was also in the first month of 1941 that Prime Minister Pál Teleki made the following, strictly confidential appeal to Radocsay: "in order to effectively support the foreign information work of Department IV operating under my direct supervision within the framework of the Hungarian Royal Prime Minister's Office, it is necessary that the ministries and other bodies regularly provide the Department with all the information that, after proper processing, can provide foreign countries with favourable information on Hungary, its domestic situation, foreign policy, development, nationality policy, economic and technical achievements, measures to promote increased production, etc.". Teleki also considered it advisable for the Ministry of Justice to inform the Prime Minister's Department of Information regularly, preferably on a weekly basis, of "the relevant decrees and the political, cultural, economic etc. measures", issued within its competence, which demonstrate the advancement and steady development of Hungary on the one hand, and can portray Hungarian nationality politics in a good light on the other. Furthermore, he also found it necessary that the statements made by nationalities, persons belonging to them and their leaders "which reveal that the situation in Hungary and the measures of the Hungarian Government elicit recognition and friendly feelings among our minorities" should also be reported to the Prime Minister's Office regularly. In order to achieve this, a ministry rapporteur was responsible for direct contact, and the compilations prepared for the Service for National Policy had to be sent to the Prime Minister's Office, too. ${ }^{15}$

Radocsay was also contacted directly by Alajos Alföldi, Head of the Service for National Policy, who pointed out: "it seems particularly useful [...] to disclose the ordered investments, facilities and the costs spent on or allocated to these, so that the public activities of the state that are less known but of great interest to the public can also be publicized." He was explicit in pointing out that the aim was to make it appear that, despite the wartime conditions in the country, "the rate of material and moral value production continues to be vibrant and, in contrast with any other continental state, the standard of living and the possibilities of obtaining basic commodities

${ }^{13}$ MNL OL K577, L.8. 1940. File No. 44.068.

14 Országépités was published in Budapest between 1941 and 1944. As a periodical bulletin all together it had 90 issues according to the database of the Library of the Hungarian Parliament. It is available digitally in parts in the collection of Arcanum.hu.

${ }^{15}$ MNL OL K577, L.8. 1940. File No. B.43/1941. 
barely decreased." The reports had to be submitted so that the data would be available to the Service on the 4th and 19th day of each month. ${ }^{16}$ For example, the economic and prison department of the Ministry of Justice soon reported the changes in the official name of the staff of court prisons, investments made in the prisons of Vác and Rákospalota, and how the prisons in Szamosújvár (Gherla) and Kolozsvár (Cluj) were organized for the territories re-annexed from Transylvania. ${ }^{17}$

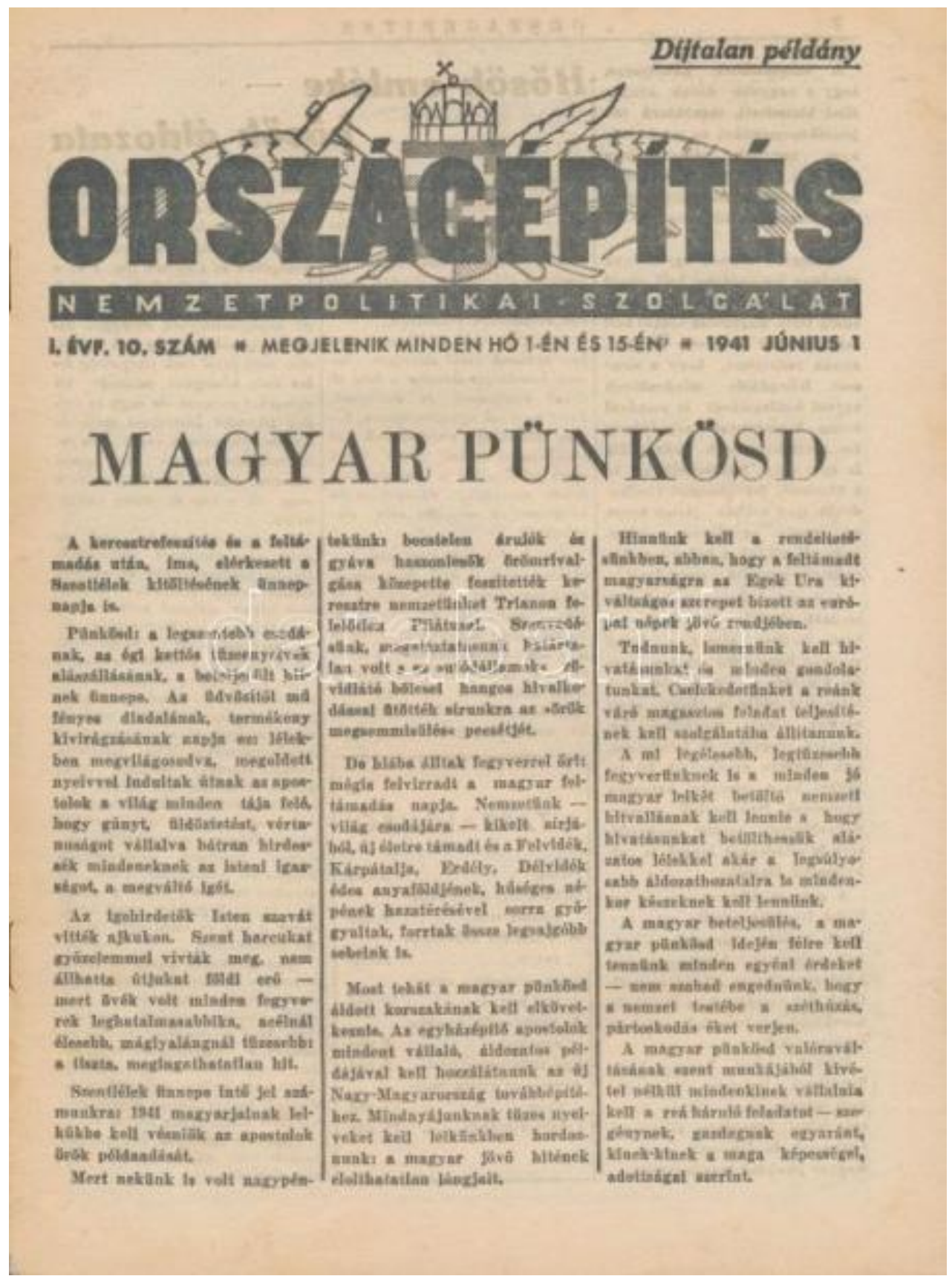

Fig. 1: Országépítés (Landbuilding). Journal of the Service for National Policy

${ }^{16}$ MNL OL K577, L.8. 1940. A file dated: 5 December, 1940.

${ }^{17}$ MNL OL K577, L.8. 1940. Files No. 67.818/1940, 468 and 469/1941. I.M.V., and files with no numbers. 
The family law department of the Ministry of Justice issued its first report on 3 January, 1941. In this, Miklós Staud, Head of Department, used this radical metaphor, among others: "in the field of family law, the Government is driven by the clear realization, or even certain knowledge of the fundamental doctrine of state that the core unit of the state is the family based on marriage blessed with profound moral content, enduring solidity and natural reproduction. [...] A man who remains unmarried, a woman who is averse to serious, stable marriage can only be regarded as a white blood cell and treated accordingly by the state with respect to governance, the proliferation of which white blood cell would cause the state to be mainly morally, but also economically and ultimately physically ill and extinct; but married couples without children or with one child can also be looked upon as nothing more than blood cells which, although looking red, are non-viable, endangered and leading to the extinction of the entire organism." This is how the submitter explained the Government's ambition, according to which "anomalous or shameful" family relationships had to be dealt with in the field of law, too, with the promotion of healthy "state red blood cell formation". With this in mind, the Ministry's usual approach in judging requests for exemption from marriage impediments was that it proposed to refuse permission only if its issuance would raise a serious moral or public health issue, or "if the marriage would only serve as a pretext or an opportunity for a foreign person to settle down in the country whose settlement was contrary to public interest". The judicial administration also supported starting a family through legal guidance and the "warm embrace" of adoption; besides, it sought to provide for the "legally forsaken": the illegitimate children through securing pardon by the Head of State. ${ }^{18}$

However, the report typically shunned the contradiction between anti-Jewish legislation and the above goals.

\section{New task of the Supervising Authority of Public Interests coming from the implementation of the Jewish laws}

In contrast, the Jews were very much focussed on in the informative anonymous commentary on the government decree ${ }^{19}$ regulating the payments on dismissal and remunerations of similar nature paid to private employees dismissed or to be dismissed as a result of the so-called Jewish laws (1939-41). ${ }^{20}$ The reason for its issuance was that persons who were classified as Jews and excluded from employment were paid large amounts of severance pay by the economic companies concerned, which was found quite injurious by the Council of Ministers, which made it compulsory to declare the emoluments paid in this way: "in reality, several companies were rather willing to risk collapse, displacement from production, but they wanted to compensate the dismissed Jews abundantly for life". The Government took measures in order to "protect" movable capital by limiting the extent of severance pays, bonuses and private pensions.

To this end, the Supervising Authority of Public Interests (Közérdekeltségek Felügyelő Hatósága), formerly established in 1933, was authorized to rectify payments that thus became unlawful, even ex officio or retrospectively, to the allowed extent, and to sanction the leaders of companies providing excessive payments. The scope of the regulation did not cover employees

\footnotetext{
${ }^{18}$ MNL OL K577, L.8. 1940. A file with no number.

${ }^{19}$ Decree of the Hung. Royal Government No. 1.500/1941.

${ }^{20}$ VÉRTES, Magyarországi zsidótörvények 19-155.
} 
receiving wages below five hundred pengős a month, cynically classifying it as the "consideration of social aspects". ${ }^{21}$ This briefly outlined document was clearly just a law extract, but it portrays vividly how the legal and economic dimensions of antisemitism were widening and how a part of the society was trying to resist this with its own means before the country entered the war. Incidentally, by the end of 1939, 28 judges and one prosecutor were made to retire as a consequence of the Second Jewish Law (Act IV of 1939) and its implementing regulations, and four court drafters were subject to the provisions of this act. ${ }^{22}$

\section{The mission of Minister Gábor Vladár at the end of the Horthy era}

The last Minister of Justice of the Horthy era, who was appointed by the Governor of his own will, was Gábor Vladár, who worked in the Government of Géza Lakatos between 29 August and 16 October, 1944. ${ }^{23}$ The minutes of the Council of Ministers reveal that a draft of a judicial decree was also prepared in order to release some of the assets belonging to fideicomissum from the restriction, but it did not actually become law. ${ }^{24}$ It is known from other sources that Vladar intervened personally and other ways between 9 and 12 October to release a number of political prisoners, which required secret normative decisions, similarly to working out the decree on banning the extreme right-wing press and authorizing the left-wing press, which was on the agenda of the government meeting held on 14 October, 1944, the last one before the "attempt to jump out of the war". Interestingly, he did not write about the latter in his memoirs. ${ }^{25}$

At the meeting of the Council of Ministers on 27 September, it was also he who, in agreement with the Minister of Trade and Transport, presented a draft decree for the use of the business, industrial goods and material stocks as well as other assets of Jews, which was adopted by the members of the Government: it was issued with number 3.520/1944. M.E. ${ }^{26}$ At the meeting on 13 September, decisions were made on several judicial personnel matters: on filling the posts of judge and prosecutor. ${ }^{27}$ These were probably not implemented de facto.

During Vladar's ministership, the Ministry of Justice also struggled with a severe budget deficit: the necessity of applying for a supplementary loan was raised at the Council of Ministers meetings held in September. According to the detailed reasons, the retrospective award of 347,000 pengôs was requested by the Ministry into the sub-fund "implementation of criminal court decisions" of the state budget of the current year, since the Ministry's budget "was almost entirely exhausted" after paying the price of the up-to-date spinning machines purchased for the hemp processing plant operating in the royal district prison of Szeged. The Government agreed to the amount requested, which was equal to the purchase price of the machines. ${ }^{28}$

Although Vladár explicitly stated in the Council of Ministers on 1 September, 1944 that in order to achieve the goals of the Government (to jump out of the war) it was essential to "improve

\footnotetext{
${ }^{21}$ MNL OL K577, L.8. 1940. A file with no number.

22 Magyarország igazságügye az 1939. évben I-II. 8.

${ }^{23}$ IK 1944:9. 331.

${ }^{24}$ MNL OL Mt., 6 September, 1944: Nr. 6.

25 RÉVÉSZ, Vladár Gábor emlékkötet 121-126. See also VLADÁR, Visszaemlékezéseim 234-235.

${ }^{26}$ IK 1944:9. 326.; MNL OL Mt. 27 September, 1944: Nr. 35.; VÉRTES, Magyarországi zsidótörvények 355.

${ }^{27}$ MNL OL Mt. 13 September, 1944: Nr. 5.

${ }^{28}$ MNL OL Mt. 6 September, 1944: Nr. 7; 27 September, 1944: Nr. 34.
} 
the performance of official duties, to maintain order and discipline in public offices to the utmost degree", ${ }^{29}$ confronting the Third Reich finally resulted in total failure - largely because of the efficient intelligence of the German secret service and the betrayal by some officers of the Hungarian general staff. ${ }^{30}$ Governor Hortby - to save his and his son's life - handed over power to the Arrow Cross Party (Hungarian national socialists), which signalled the end of the history of the Ministry of Justice in the bourgeois era.

\section{Literature and sources}

ANTAL Tamás: A Szegedi Királyi Ítélőtábla története 1914 és 1921 között [A History of the Royal Appeal Court of Szeged between 1914 and 1921]. Bíróságtörténeti könyvek. Fejezetek a Szegedi Ítélőtábla történetéből II. Budapest - Szeged 2015

Decree of the Hung. Royal Government No. 7.780/1938 [A m. kir. minisztériumnak 7.780/1938. M.E. sz. rendelete a Magyar Szent Koronához visszacsatolt területekre vonatkozó igazságügyi rendelkezések tárgyában. In: Igazságügyi Közlöny (=IK) 1938:10.305.]

Decree of the Hung. Royal Government No. 9.600/1938 [A m. kir. minisztériumnak 9.600/1938. M.E. sz. rendelete a felvidéki területeknek a Magyar Szent Koronához visszacsatolásával kapcsolatos igazságügyi szervezeti rendelkezések tárgyában. IK 1938:12. 340-345.]

Decree of the Hung. Royal Government No. 5.800/1939 [A m. kir. minisztériumnak 5.800/1939. M.E. sz. rendelete a Magyar Szent Koronához visszatért kárpátaljai területekre vonatkozó igazságügyi szervezeti rendelkezések tárgyában. IK 1939:6. 135-138.]

Decree of the Hung. Royal Government No. 7.810/1940 [A m. kir. minisztériumnak 7.810/1940. M.E. sz. rendelete a keleti és erdélyi országrésznek a Magyar Szent Koronához visszacsatolásával kapcsolatos igazságügyi szervezeti rendelkezések tárgyában. IK 1940:11. 249-253.]

Decree of the Hung. Royal Government No. 5.470/1941 [A m. kir. minisztériumnak 5.470/1941. M.E. sz. rendelete a visszafoglalt délvidéki területre vonatkozó igazságügyi szervezeti rendelkezések tárgyában. IK 1941:7. 267270.]

Decree of the Hung. Royal Government No. 6.100/1941 [A m. kir. minisztériumnak 6.100/1941. M.E. sz. rendelete az anyakönyvi közigazgatásra és a házasságkötési eljárásra vonatkozó jogszabályoknak a visszafoglalt délvidéki területen való hatályba léptetése tárgyában. IK 1941:8. 320.]

Decree of the Hung. Royal Government No. 7.600/1941 on the amendment of the pervious one [7.600/1941. M.E. sz. rendelet, IK 1941:10. 368-369.]

Decree of the Hung. Royal Government No. 6.140/1941 [A m. kir. minisztériumnak 6.140/1941. M.E. sz. rendelete a Délvidéki Földbirtokrendezési Tanács szervezése tárgyában. IK 1941:8. 320-321.]

Decree of the Hung. Royal Government No. 7.550/1941 [A m. kir. minisztérium 7.550/1941. M.E. sz. rendelete a személyi és családi jog egyes rendelkezéseinek a visszafoglalt délvidéki területen hatályba léptetése tárgyában. IK 1941:10. 363.]

Decree of the Hung. Royal Government No. 1.930/1942 [A m. kir. minisztériumnak 1.930/1942. M.E. sz. rendelete a visszacsatolt délvidéki területeken a társadalombiztosítási bíráskodásra vonatkozó magyar jogszabályok hatálybaléptetése tárgyában. IK 1942:3. 73-74.]

Decree of the Hung. Royal Government No. 2.810/1942 [A m. kir. minisztériumnak 2.810/1942. M.E. sz. rendelete a visszacsatolt délvidéki területeken a magyar magánjog hatálybaléptetése tárgyában. IK 1942:5. 193-209.]

Decree of the Hung. Royal Government No. 5.620/1941 [A m. kir. minisztériumnak 5.620/1941. M.E. sz. rendelete a visszafoglalt délvidéki területen a kir. bíróságok és a kir. ügyészségek működésének megkezdése tárgyában. IK 1941:7. 270.]

${ }^{29}$ MNL OL Mt. 1 September, 1944: Nr. 26.

30 VLADÁR, Visszaemlékezéseim 235-245. 
Decree of the Hung. Royal Government No. 6.150/1941 [A m. kir. minisztériumnak 6.150/1941. M.E. sz. rendelete a visszafoglalt délvidéki területre vonatkozó igazságügyi szervezeti rendelkezések kiegészítése tárgyában. IK 1941:8. 319.]

Decree of the Hung. Royal Government No. 8.000/1941 [A m. kir. minisztériumnak 8.000/1941. M.E. sz. rendelete az újvidéki és a zombori kir. törvényszéknek jövedéki büntető bírósági hatáskörrel felruházása tárgyában. IK 1941:11. szám. 403.]

Decree of the Hung. Royal Government No. 610/1942 [A m. kir. minisztériumnak 610/1942. M.E. sz. rendelete a visszafoglalt délvidéki területre vonatkozó igazságügyi szervezeti rendelkezések módosítása tárgyában. 1942:1. 1.]

Decree of the Hung. Royal Government No. 5.480/1941 [A m. kir. minisztériumnak 5.480/1941. M.E. sz. rendelete a visszafoglalt délvidéki területen a polgári peres eljárás és egyes nemperes eljárások szabályozása tárgyában. IK 1941:7. 272-282. (1-6. (5)]

Decree of the Hung. Royal Government No. 730/1942 [A m. kir. minisztériumnak 730/1942. M.E. sz. rendelete a visszafoglalt délvidéki területen a polgári peres eljárás és egyes nemperes eljárások szabályozásáról szóló 5.480/1941. M.E. sz. rendelet kiegészítése tárgyában. IK 1942:2. 51.]

Decree of the Hung. Royal Government No. 1.990/1942 [A m. kir. minisztériumnak 1.990/1942. M.E. sz. rendelete a polgári peres és nemperes eljárásban, valamint a magánjogi kötelezettségek tárgyában a háború következtében szükségessé vált kivételes szabályok megállapításáról. IK 1942:3. 65-73.]

Decree of the Hung. Royal Government No. 5.490/1941 [A m. kir. minisztériumnak 5.490/1941. M.E. sz. rendelete a visszafoglalt délvidéki területen a magyar polgári büntetőbíráskodás működésének megkezdése tárgyában. IK 1941:7. 293-295. (1-15. \$S)]

Decree of the Hung. Royal Government No. 1.500/1941 [A m. kir. minisztérium 1.500/1941. M.E. sz. rendelete a magánalkalmazottak szolgálati jogviszonyának megszűnése esetére járó illetményekről. In: Magyarországi Rendeletek Tára 1941. Budapest, 1942, 166-173.]

Magyarország igazságügye az 1939. évben. [Judicature of Hungary in the Year of 1939: Separatum from the official governmental report of 1939]. Budapest 1942

MNL OL = Hungarian National Archives K577, B.5. 1941; B.7. 1941; B.8. 1941-1944; L.8. 1940

MNL OL Mt.= Hungarian National Archives, Official minutes of the Council of Ministers

RADY, Martyn: Nonnisi in sensu legum? Decree and Rendelet in Hungary (1790-1914). Hungarian Historical Review No. 1/2016 5-21.

RÉVÉSz BÉLA (ed.): Vladár Gábor emlékkötet (1881-1972) [A Memorial Book in Honour of Gábor Vladár (18811972)]. Budapest 2015

VÉRTES Róbert: Magyarországi zsidótörvények és rendeletek, 1938-1945 [jewish Acts and Decrees in Hungary, 1938-1945]. Budapest 1997

VLADÁR Gábor: Visszaemlékezéseim [My Memoires]. Budapest 1997 